\title{
Impact of human immunodeficiency virus (HIV) infection in patients undergoing cardiac surgery: a systematic review
}

\author{
Carmelo Dominici ${ }^{1, *}$ and Massimo Chello ${ }^{1}$ \\ ${ }^{1}$ Cardiovascular surgery, Campus Bio-Medico University of Rome, Rome, Italy \\ *Correspondence: c.dominici@unicampus.it (Carmelo Dominici)
}

DOI: $10.31083 /$ i.rcm.2020.03.104

This is an open access article under the CC BY 4.0 license (https://creativecommons.org/licenses/by/4.0/).

The clinical status and prognosis of patients with human immunodeficiency virus (HIV) infection has dramatically changed in the recent years. Cardiovascular diseases can be related to combined antiretroviral therapy and to the aging of HIV-positive population, resulting in significant mortality and morbidity in those patients. It is crucial to understand whether the HIV-status affects the indications and outcomes of cardiac surgery. A literature search was conducted through electronic databases up to 15 May 2020 following PRISMA guidelines. Variables (i.e. patients characteristics) and endpoints (i.e. postoperative complications) were considered as defined in the original publications. All paper describing post-operative outcomes after cardiac surgery were included. Methodological quality of all included studies was assessed using the Newcastle-Ottawa Scale, the Cochrane Risk of Bias tool and the US Preventive Services Task Force grade. A total of eight studies were included in this systematic review; five studies discussed the outcomes of patients with HIV infection, while three studies compared results based on HIV status. All evidences derived from retrospective observational studies with high variability and poor-to-fair quality. Most patients underwent surgical myocardial revascularization. HIV status is not associated with differences in operative mortality $(P=0.32)$, postoperative mediastinitis ( $P$ $=0.30)$ or pulmonary infective complications $(P=0.67)$. Cardiac surgery can be considered safe in HIV-positive patients, and HIV status alone should not be considered as a contraindication for cardiac surgery and should not be considered a risk factor for postoperative mortality or perioperative complications. Further studies are required for patients with AIDS.

\section{Keywords}

HIV; cardiac surgery; coronary artery bypass; valve replacement; heart surgery

\section{Introduction}

The availability and use of combined anti-retroviral therapy (CART) have dramatically improved long-term outcomes in HIVpositive patients and transformed HIV infection into a chronic disease (Erqou et al., 2020, 2019; Feinstein et al., 2016; Siegfried et al., 2010). However, the prolonged life expectancy with good quality of life is associated with increasing prevalence of cardiovascular disease, which remains responsible for a significant burden of complications, hospitalizations and adverse events (Deeks et al., 2015; Manmathan et al., 2020; Yanagawa et al., 2019). Compared with general population, patients with HIV have a 4.5-fold increased risk of sudden cardiac death after adjustment for age and gender (Tseng et al., 2012). Besides a higher incidence of traditional risk factors in patients with HIV (D'Ascenzo et al., 2012; Rethy et al., 2020; Sinha and Feinstein, 2020, 2019), infection carries an additional 1.5- to 2-fold increased independent risk of acute myocardial infarction (Freiberg et al., 2013) or coronary artery disease (Bernelli et al., 2020; Longenecker et al., 2020; Peck and Kingery, 2020). The mechanisms of HIV-related coronary artery disease have been investigated in recent years, and activation of toll-like receptor 2 and formation of neutrophil extracellular traps result in chronic inflammation and endothelial dysfunction (Pallikkuth et al., 2018; Sinha and Feinstein, 2020, 2019; Stein et al., 2014; Subramanian et al., 2012; Titanji et al., 2020). This results in a more aggressive and early-onset of the disease (Bernelli et al., 2020; Nou et al., 2016; Rethy et al., 2020; Titanji et al., 2020). HIV-accelerated coronary artery disease, non-ischemic heart disease, opportunistic infections and drug-related myocardial damage warrant special attention in this population for the near future (Bernelli et al., 2020; Erqou et al., 2020, 2019; Manga et al., 2017; Manmathan et al., 2020; Vachiat et al., 2017; Wong et al., 2020; Yanagawa et al., 2019). Treatment of coronary artery disease, valvular disease of pathologies of the ascending aorta might require cardiac surgery procedures and therefore it is crucial to understand whether the HIV-status affects the indications and outcomes of cardiac surgery. This systematic review aims to summarize the current literature about cardiac surgical management in patients with HIV.

\section{Methods}

We followed PRISMA guidelines for performing and reporting the present systematic review (Supplementary Table I). A literature search was conducted through PubMed, Embase, EBSCO, Cochrane database of systematic reviews, and Web of Science from their inception up to 15 May 2020 using the following search keywords (and their MeSH terms) in various combinations: "coronary artery bypass graft", "myocardial revasculariza- 


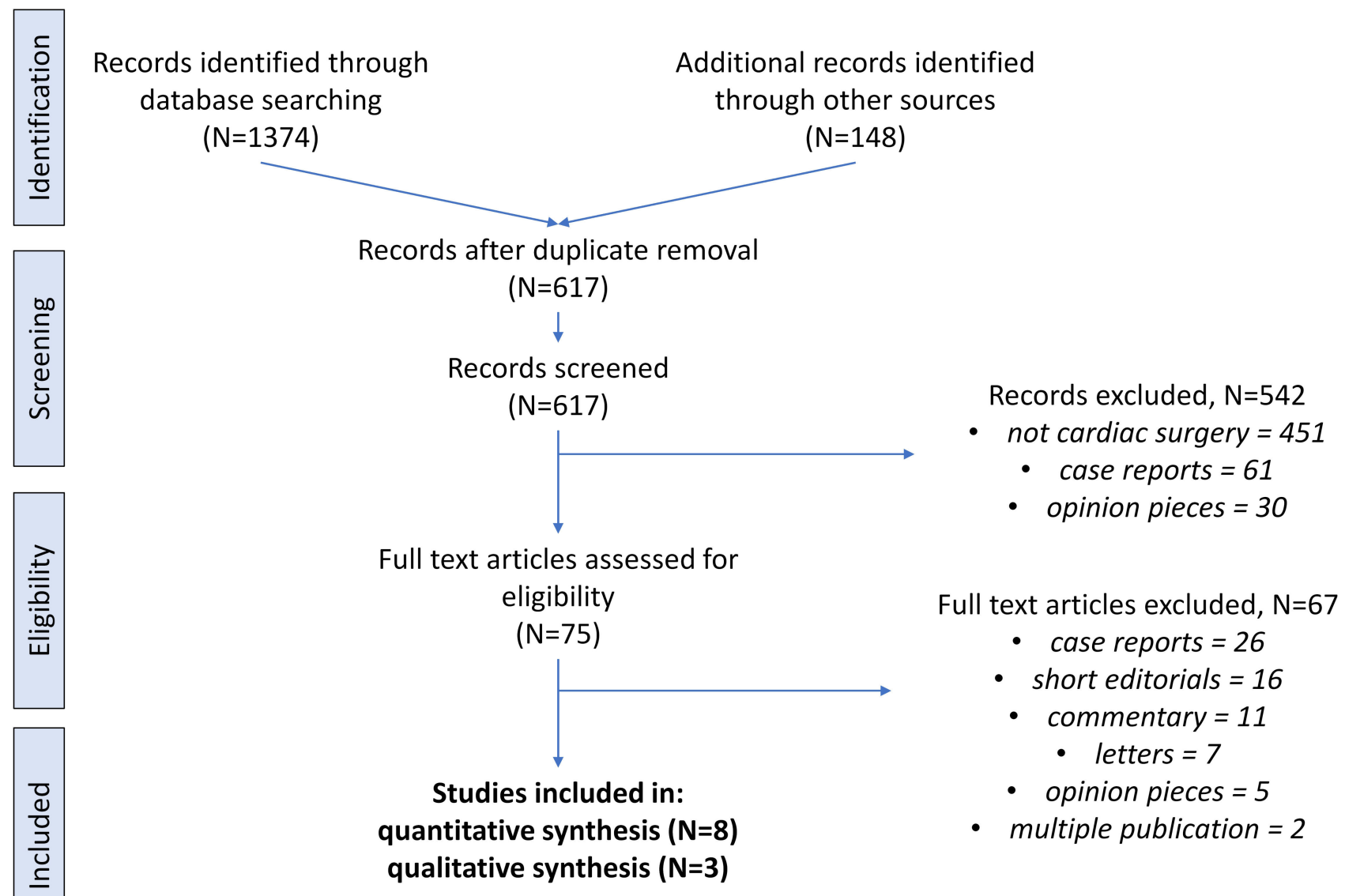

Fig. 1. PRISMA flow diagram. The flow diagram depicts the flow of information through the different phases of a systematic review. Studies included in quantitative synthesis (meta-analysis): 8 . Studies included in qualitative synthesis: 3 .

tion", "cardiac surgery", "extracorporeal membrane oxygenation", "transplantation", "cardiac", "heart", "valve replacement", "HIV", "AIDS". We also reviewed references of all articles from the literature. We included all papers describing post-operative outcomes after any procedure of cardiac surgery (i.e. myocardial revascularization, valve surgery,...). All investigators reviewed the studies to determine their eligibility and independently extracted all the relevant outcomes of interest. Data from all eligible studies using a standardized file, focusing on study design, study size, type of intervention and outcomes were retrieved only from the articles, and no attempt was made to get missing data from the authors. Any disagreement was solved by consensus. Inclusion and exclusion criteria were summarized according to the PICOS (population, intervention, comparator, outcomes, and study design) approach (Table 1). Year of publication, study design, sample size, number of patients in each treatment group, measured outcomes, baseline patient characteristics and outcomes were extracted. Variables (i.e. patients characteristics) and endpoints (i.e. postoperative complications) were considered as defined in the original publications. Methodological quality of all included studies was assessed using the Newcastle-Ottawa Scale, the Cochrane Risk of Bias tool and the US Preventive Services Task Force grade.

\section{Results}

Literature search yielded a total of 1374 records, and 8 studies (Boccara et al., 2008; Brogan et al., 2020; Chong et al., 2003; Koval et al., 2019; Mestres, 2003; Polanco et al., 2014; Robich et al., 2014; Trachiotis et al., 2003) were included in the systematic review (PRISMA flow diagram, Fig. 1). Quality assessment is shown in Table 2, and study characteristics and collected outcomes are summarized in Table 3, Table 4 and Table 5.

A total of five studies discussed the outcomes of patients with HIV infection, as a single cohort of patients (Brogan et al., 2020; Chong et al., 2003; Koval et al., 2019; Mestres, 2003; Trachiotis et al., 2003), while three studies compared results from HIV-positive and HIV-negative patients (Boccara et al., 2008; Polanco et al., 2014; Robich et al., 2014). All evidences derived from retrospective observational studies with high variability and poor-to-fair quality (Table 2), as HIV-status cannot be considered a randomization factor for ethical concerns. Robich et al. (2014) reported the outcomes before and after propensity score matching, although long-term results were not investigated. In this study, propensity scores, or the conditional probability of being HIV-positive, were estimated using a multivariable logistic regression model in which the presence of HIV was the dependent variable; patient demographics, payer status, comorbidities, hospital characteristics, and procedure type were the independent variables. The aim 


\section{Mortality}

\begin{tabular}{|c|c|c|c|c|c|c|c|c|}
\hline Study or Subgroup & $\begin{array}{l}\text { HIV+ } \\
\text { Events }\end{array}$ & Total & $\begin{array}{l}\text { HIV } \\
\text { Events }\end{array}$ & Total & Weight & $\begin{array}{c}\text { Odds Ratio } \\
\text { M-H, Random, } 95 \% \mathrm{Cl}\end{array}$ & $\begin{array}{c}\text { Odds Ratio } \\
\text { M-H, Random, } 95 \% \mathrm{Cl}\end{array}$ & \\
\hline Boccara et al. 2008 & 0 & 27 & 0 & 54 & & Not estimable & & \\
\hline Polanco et al. 2014 & 32 & 1239 & 26720 & 809701 & $39.8 \%$ & $0.78[0.55,1.10]$ & & \\
\hline Robich et al. 2014 (PSM) & 100 & 1633 & 102 & 1633 & $60.2 \%$ & $0.98[0.74,1.30]$ & & \\
\hline Total $(95 \% \mathrm{CI})$ & & 2899 & & 811388 & $100.0 \%$ & $0.89[0.72,1.12]$ & & \\
\hline Total events & 132 & & 26822 & & & & & \\
\hline $\begin{array}{l}\text { Heterogeneity: } \mathrm{Tau}^{2}=0.00 \\
\text { Test for overall effect: } Z=\end{array}$ & $\begin{array}{l}\mathrm{Chi}^{2}=1.0 \\
00(P=0 .\end{array}$ & $\begin{array}{l}01, \mathrm{df}= \\
.32)\end{array}$ & $1(P=0.3$ & $32) ;\left.\right|^{2}=1$ & & 0.2 & $\begin{array}{cc}0.5 & 1 \\
\text { Favours HIV+ Favours } \mathrm{HI}\end{array}$ & 5 \\
\hline
\end{tabular}

\section{Stroke}

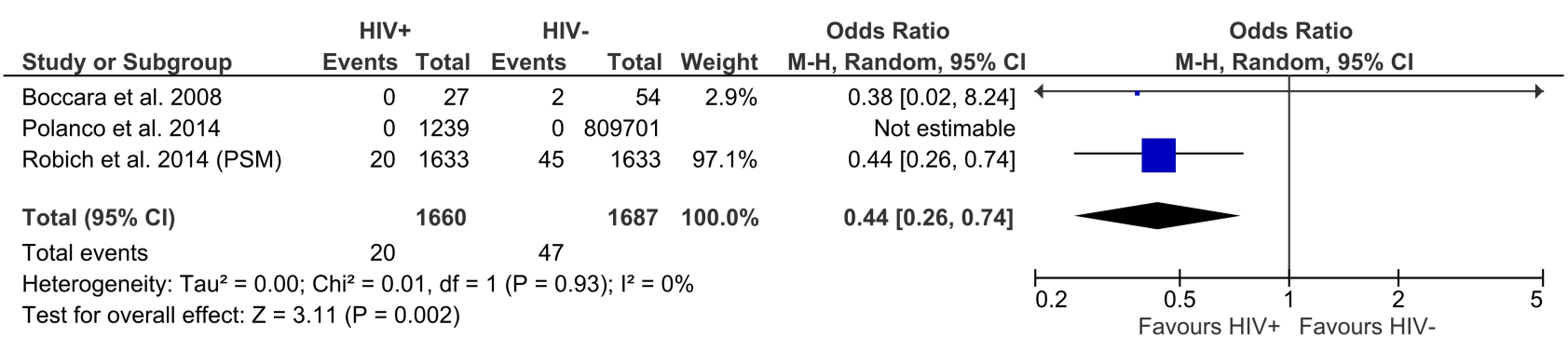

\section{Mediastinitis}

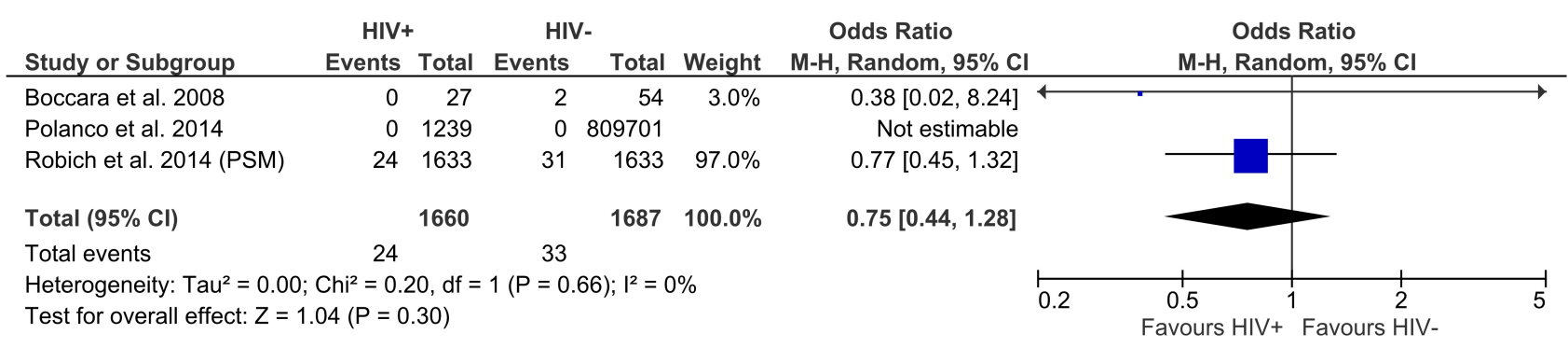

\section{Pulmonary complications}

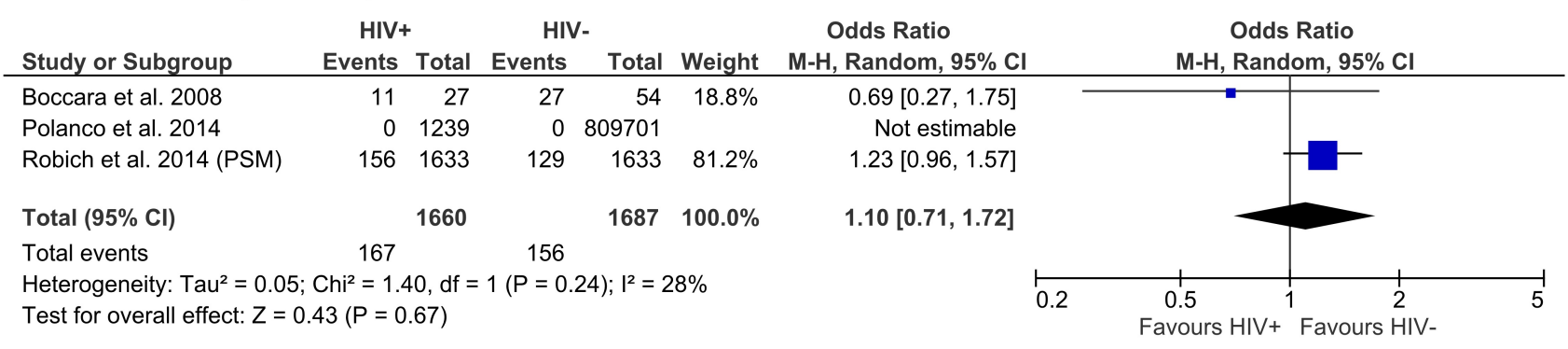

Fig. 2. Pooled results from the studies available in the literature comparing outcome of HIV-positive and HIV-negative patients. Analysis was performed comparing the number of events as described in original publications. Mortality, stroke, mediastinitis and pulmonary complications were evaluated as endpoints. A random-effect model was used with Mantel-Haenszel method. Effects were evaluated as odds ratios (OR).

of this propensity score was to balance covariates to assess outcomes without the influence from known factors. Most patients underwent revascularization with CABG, and other evaluated procedures were aortic valve replacement and mitral valve surgery
(Table 3). No data about procedures on the ascending aorta are available, as well as cardiac tumours, tricuspid valve disease and combined procedures. 
Table 1. PICOS criteria for inclusion and exclusion of studies.

\begin{tabular}{|c|c|c|}
\hline Parameter & Inclusion criteria & Exclusion criteria \\
\hline Patients & Adult patients ( $\geq 18$ years) & - \\
\hline Intervention & $\begin{array}{l}\text { Any procedure of cardiac surgery (myocardial revascularization, valve } \\
\text { surgery, surgery of the thoracic aorta, ...) }\end{array}$ & Percutaneous procedures \\
\hline \multirow[t]{2}{*}{ Comparator } & HIV status & - \\
\hline & Primary: mortality & - \\
\hline \multirow[t]{4}{*}{ Outcomes } & Secondary: postoperative complications & \\
\hline & Secondary: long-term complications & \\
\hline & Clinical randomised trials & Repeat publications of the same dataset \\
\hline & Controlled before-and-after studies & Conference abstracts \\
\hline \multirow{4}{*}{ Study design } & Prospective and retrospective cohort studies & Non-systematic review articles \\
\hline & Cross-sectional studies & Review / editorials / opinion pieces \\
\hline & Case-control studies & Books or grey literature \\
\hline & Meta-analyses & Case reports ( $\leq 10$ patients) \\
\hline
\end{tabular}

Table 2. Quality assessment of the included studies.

\begin{tabular}{|c|c|c|c|c|c|c|c|c|c|}
\hline \multirow{2}{*}{ Study } & \multicolumn{3}{|c|}{ Newcastle-Ottawa Scale } & \multicolumn{5}{|c|}{ Cochrane Risk of Bias Analysis } & \multirow{2}{*}{ US-PSTF grade } \\
\hline & Selectiol & nparal & Outco & Selectior & Performan & Detection & Attrition & Reporting & \\
\hline (Boccara et al., 2008) & $* *$ & $* *$ & $* *$ & High & High & High & Low & Low & Poor \\
\hline (Brogan et al., 2020) & $* * *$ & $* *$ & $* *$ & Low & High & High & Low & Low & Fair \\
\hline (Chong et al., 2003) & $* *$ & $* *$ & $* *$ & High & High & High & Low & Low & Poor \\
\hline (Koval et al., 2019) & $* *$ & $* *$ & $* *$ & High & High & High & Low & Low & Poor \\
\hline (Mestres, 2003) & $* *$ & $* *$ & $* *$ & High & High & High & Low & Low & Poor \\
\hline (Polanco et al., 2014) & $* * *$ & $* * *$ & $* *$ & Low & High & High & Low & Low & Fair \\
\hline (Robich et al., 2014) & $* * *$ & $* * *$ & $* *$ & Low & High & High & Low & Low & Fair \\
\hline (Trachiotis et al., 2003) & $* *$ & $* *$ & $* *$ & High & High & High & Low & Low & Poor \\
\hline
\end{tabular}

\subsection{Pooled analysis}

Pooled results from the 3 studies available in the literature (Boccara et al., 2008; Polanco et al., 2014; Robich et al., 2014) comparing outcome of HIV-positive and HIV-negative patients are shown in Fig. 2. Operative mortality in patients with HIV was similar to non-HIV patients (odds ratio $0.89,95 \%$ confidence interval $0.72-1.12, P=0.32$ ). Postoperative mediastinitis and pulmonary infective complications also appeared to be independent from the HIV status ( $P=0.30$ and $P=0.67$, respectively). Notably, stroke risk appeared to be reduced among HIV-positive patients (odds ratio $0.44,95 \%$ confidence interval $0.26-0.74, P=0.002$ ) (Robich et al., 2014; Sullivan et al., 2015).

\section{Discussion}

Cardiac surgery is generally associated with a strong postoperative inflammatory reaction, related to cardiopulmonary bypass, aortic manipulation and general anaesthesia (Corral-Velez et al., 2015; Giacinto et al., 2019; Squiccimarro et al., 2019). Preliminary reports indicated an increased risk of weakening the immune system in HIV-positive patients (Yanagawa et al., 2019), although this was not subsequently documented by the clinical experience.

\subsection{Cardiac surgery is safe in HIV patients}

Major studies in HIV patients (Polanco et al., 2014; Robich et al., 2014) report a 2.5-fold increase in the frequency of cardiac surgery among HIV-positive patients. However, HIV status was not an independent predictor of perioperative mortality following cardiac surgery, as shown in our pooled analysis (odds ratio 0.89 , 95\% confidence interval 0.72-1.12). This reflects the observations of Polanco et al(Polanco et al., 2014) (odds ratio 0.88, 95\% confidence interval 0.6-1.2) and Robich et al. (2014) odds ratio 0.8, 95\% confidence interval 0.74-1.30). Independent predictors of mortality were age, renal failure and non-CABG procedure, similarly to HIV-negative population (Yanagawa et al., 2019). HIV status alone should not be considered as a contraindication for cardiac surgery and should not be considered a risk factor for postoperative mortality or perioperative complications. On the contrary, the observed postoperative stroke reduction in HIV-positive patients could be secondary to differences in immunomodulation, decreased inflammatory or atherosclerotic burden, younger age, reduced incidence of postoperative atrial fibrillation or reduced peripheral vascular disease (Robich et al., 2014; Sullivan et al., 2015; Yanagawa et al., 2019), but conclusive data are lacking and details about postoperative stroke are not available from Polanco et al., to support those data (Polanco et al., 2014). Similarly, it is possible to reliably speculate that HIV status does not impair long-term outcomes, but data are needed to support this conclusion. 
Table 3. Details of the included studies.

\begin{tabular}{|c|c|c|c|c|}
\hline Study & Patients & Design & Procedures & Age (years) \\
\hline (Boccara et al., 2008) & $\begin{array}{l}27 \mathrm{HIV+} \\
54 \mathrm{HIV}-\end{array}$ & retrospective & $100 \%$ on-pump CABG & $47.3 \pm 11.2$ vs $50.4 \pm 5.4$ \\
\hline (Brogan et al., 2020) & $126 \mathrm{HIV}+$ & retrospective & $\begin{array}{l}\text { xtracorporeal membrane oxy } \\
34 \text { veno-arterial } \\
88 \text { veno-venous }\end{array}$ & 40 \\
\hline (Chong et al., 2003) & $22 \mathrm{HIV}+$ & retrospective & $\begin{array}{c}12 \text { AVS } \\
7 \text { MVS } \\
3 \text { AVS+MVS }\end{array}$ & 37.6 \\
\hline (Koval et al., 2019) & $21 \mathrm{HIV}+$ & retrospective & $100 \%$ heart transplantation & 48 \\
\hline (Mestres, 2003) & $31 \mathrm{HIV+}$ & retrospective & $\begin{array}{c}21 \text { endocarditis } \\
5 \mathrm{CABG} \\
5 \text { non-endocarditis }\end{array}$ & 33.1 \\
\hline (Polanco et al., 2014) & $\begin{array}{r}1239 \text { HIV+ } \\
809701 \text { HIV- }\end{array}$ & retrospective & $\begin{array}{c}63.7 \% \text { vs } 73.2 \% \text { CABG } \\
36.3 \% \text { vs } 26.8 \% \text { valve } \\
49.0 \% \text { vs } 57.9 \% \text { AVS } \\
35.7 \% \text { vs } 30.0 \% \text { MVS }\end{array}$ & $51.9 \pm 9.8$ vs $65.3 \pm 12.4$ \\
\hline (Robich et al., 2014), retrospective cohort & $\begin{array}{r}9771 \mathrm{HIV+} \\
5621817 \mathrm{HIV}- \\
\end{array}$ & retrospective & $\begin{array}{l}16 \% \text { vs } 10 \% \text { valve } \\
38 \% \text { vs } 59 \% \text { CABG }\end{array}$ & $48.9 \pm 0.25$ vs $65.6 \pm 0.05$ \\
\hline (Robich et al., 2014), PSM cohort & $\begin{array}{l}1633 \mathrm{HIV}+ \\
1633 \mathrm{HIV}-\end{array}$ & PSM & NA & NA \\
\hline (Trachiotis et al., 2003) & $37 \mathrm{HIV}+$ & retrospective & $\begin{array}{c}27 \mathrm{CABG} \\
10 \text { valve surgeries }\end{array}$ & 41 \\
\hline
\end{tabular}

AVS: aortic valve surgery; CABG: coronary artery bypass graft surgery; LVEF: left ventricular ejection fraction; MVS: mitral valve surgery;

NA: not available; PSM: propensity score-matched

\subsection{Surgical myocardial revascularization}

As for patients with coronary artery disease, the indication between percutaneous coronary intervention (PCI) or CABG is based on patient's conditions, comorbidities and coronary anatomy. For CABG and PCI, HIV-positive patients exerted similar results to those observed in the general population (Badr et al., 2015; Bundhun et al., 2017; Moran et al., 2020). HIV-status is known to be accompanied by a pro-inflammatory status with increased platelet reactivity (Hauguel-Moreau et al., 2017; Rethy et al., 2020), but this does not seem to directly translate into clinically observable adverse events. A recent metanalysis of $821 \mathrm{HIV}$-positive and 1147 HIV-negative patients undergoing PCI demonstrated that HIVpositive patients have similar mortality (odds ratio $1.16,95 \%$ confidence interval $0.50-2.68, P=0.74$ ), no significant increase in recurrent myocardial infarction (odds ratio $1.32,95 \%$ confidence interval 0.88-2.12, $P=0.17$ ), target vessel revascularization (odds ratio 1.22 , 95\% confidence interval $0.72-2.06, P=0.46$ ) or major adverse events (odds ratio $1.47,95 \%$ confidence interval $0.44-$ $4.89, P=0.53$ ) (Bundhun et al., 2017). Those results seem to corroborate the outcomes observed in the CABG scenario. Therefore, CABG can be performed safely with good outcomes in HIVpositive patients.

\subsection{Surgical valve replacement}

As for patients with valvular heart disease, data are still lacking to draw definitive conclusions, but supporting evidences support that HIV-positive patients should be equal candidates for cardiac surgery in Heart Team discussion. The choice of valve prosthesis can be performed similarly to the overall population, weighting the life expectancy, patient's preference and risk of anticoagulation (Baumgartner et al., 2017; Nishimura et al., 2017). Patients ineligible for surgical aortic valve replacement could be evaluated for transcatheter approaches, regardless of their HIV status.

\subsection{Surgery for heart failure}

As for patients with advanced heart failure requiring cardiac surgery, besides small case series of short-term success with left ventricular assist devices or heart transplantation (Brozzi et al., 2020; Yanagawa et al., 2019), recent data from the ELSO Registry confirmed that survival in HIV-positive patients is similar to the general population in case of cardiac failure requiring veno-arterial extracorporeal membrane oxygenation (Brogan et al., 2020). Similarly, HIV-positive patients have similar survival rates to HIVnegative patients after heart transplantation (Koval et al., 2019). Therefore, recent studies confirm that HIV status does not modify outcomes of veno-arterial extracorporeal membrane oxygenation or heart transplantation compared with HIV-negative patients (Brogan et al., 2020; Koval et al., 2019). A recent analysis from the Veterans Health Affairs confirmed that HIV-positive patients have increased presence of cardiovascular risk factors and their heart failure results in a higher risk of mortality and hospitalization (Erqou et al., 2020). Worse outcomes were reported in case of lower ejection fraction, lower $\mathrm{CD}^{+}$count $(<200$ cells $/ \mathrm{mL})$ or higher HIV viral load ( $>75$ copies/muL) (Erqou et al., 2020), and therefore those patients should be adequately evaluated for adequate treatment in case of mechanical circulatory support. 
Table 4. Early outcomes.

\begin{tabular}{|c|c|c|c|c|c|c|}
\hline Study & In-hospital mortality & Myocardial infarction & Stroke & Pulmonary infection & $\begin{array}{l}\text { Reoperation } \\
\text { for bleeding }\end{array}$ & Mediastinitis \\
\hline (Boccara et al., 2008) & 0 vs 0 & 1 vs 0 & 0 vs 2 & 11 vs 27 & 4 vs 1 & 0 vs 2 \\
\hline (Brogan et al., 2020) & 81 & 4 & 8 & NA & NA & NA \\
\hline (Chong et al., 2003) & 0 & NA & 1 & NA & 0 & 0 \\
\hline (Koval et al., 2019) & 0 & NA & NA & NA & NA & NA \\
\hline (Mestres, 2003) & 7 & NA & 1 & 2 & 2 & 0 \\
\hline (Polanco et al., 2014) & $\begin{array}{c}32 \text { vs } 26720 \\
\text { (CABG: } 1.5 \% \text { vs } 2.4 \%)\end{array}$ & NA & NA & NA & NA & NA \\
\hline $\begin{array}{l}\text { (Robich et al., 2014), } \\
\text { retrospective cohort }\end{array}$ & 704 vs 242404 & NA & 113 vs 128967 & 1091 vs 296141 & NA & 125 vs 68094 \\
\hline $\begin{array}{l}\text { (Robich et al., 2014), } \\
\text { PSM cohort }\end{array}$ & 100 vs 102 & NA & 20 vs 45 & 156 vs 129 & NA & 24 vs 31 \\
\hline (Trachiotis et al., 2003) & 1 & 0 & 0 & 2 & 2 & 1 \\
\hline
\end{tabular}

Results are presented as "events in HIV-positive patients" vs "events in HIV-negative patients". NA: not available.

Table 5. Long term outcomes.

\begin{tabular}{|c|c|c|c|c|c|}
\hline Study & Follow up & Mortality & ac mortality & MACE definition & MACE events \\
\hline (Boccara et al., 2008) & $\begin{array}{l}\text { median } 41 \text { months } \\
\quad \text { (range 34-60) }\end{array}$ & 2 vs 1 & 0 vs 0 & $\begin{array}{l}\text { death for cardiac cause, non-fatal } \\
\text { MI and repeated revascularization } \\
\text { (including PCI and re-CABG) }\end{array}$ & 11 vs 10 \\
\hline (Brogan et al., 2020) & NA & NA & NA & NA & NA \\
\hline (Chong et al., 2003) & mean 5 years & 10 & NA & NA & NA \\
\hline (Koval et al., 2019) & $\begin{array}{l}\text { median } 35 \text { months } \\
\quad \text { (range 4-106) }\end{array}$ & 5 & NA & described as single outcomes & $\begin{array}{l}\text { infections at } 1 \text { year: } 8 \\
\text { rejection at } 1 \text { year: } 14\end{array}$ \\
\hline (Mestres, 2003) & mean 3.4 years & 9 & NA & NA & NA \\
\hline (Polanco et al., 2014) & NA & NA & NA & NA & NA \\
\hline $\begin{array}{l}\text { (Robich et al., 2014), } \\
\text { retrospective cohort }\end{array}$ & NA & NA & NA & NA & NA \\
\hline $\begin{array}{l}\text { (Robich et al., 2014), } \\
\text { PSM cohort }\end{array}$ & NA & NA & NA & NA & NA \\
\hline (Trachiotis et al., 2003) & 3 years & 0 & 0 & $\begin{array}{l}\text { angina, death, myocardial } \\
\text { infarction, repeat revascularization, } \\
\text { and congestive heart failure }\end{array}$ & freedom from MACE: $81 \%$ \\
\hline
\end{tabular}

Results are presented as "events in HIV-positive patients" vs "events in HIV-negative patients". CABG: coronary artery bypass graft surgery. MACE: major adverse cardiac events. NA: not applicable. PCI: percutaneous coronary intervention.

\subsection{Patients with AIDS}

Patients with AIDS (HIV-positive, low CD4 ${ }^{+}$count, opportunistic infections, secondary cancers) have limited long-term survival and literature lacks reliable data on cardiac surgery procedures. Patients with AIDS are generally considered candidate for surgery for life-saving procedures only (i.e. surgery for aortic dissection) and are generally excluded from clinical trials (Clement et al., 2018). Also, there is no consensus about the $\mathrm{CD}^{+}$count that is considered safe.

\subsection{Limitations}

Many studies did not report long-term outcomes which could not be analytically evaluated; moreover, pooled analysis could not be comprehensive due to the single-arm nature of some studies. Myocarditis either due to viral or toxoplasma pathogenesis seem not to be adequately investigated in previous studies and might represent a promising field of research for the future.

\section{Conclusions}

Prognosis of HIV-positive patients has dramatically improved in recent years, and patients can manifest heart disease requiring cardiac surgery. HIV status should be neither considered a contraindication for cardiac surgery nor a risk factor for postoperative complications. Therefore, HIV-positive patients should be considered normal candidates for cardiac surgery. Certainly, long-term outcomes and specific data for AIDS patients represent an important area of uncertainty, warranting further future investigations.

\section{Authors' contributions}

Conception of the study (all authors), acquisition of data (all authors), interpretation of data (all authors), drafting the article (CD), revision of the article (MC), final approval of the manuscript (all authors). 


\section{Acknowledgements}

We would like to express my gratitude to all those who helped me during the writing of this manuscript

\section{Conflict of interest}

All authors declare no conflicts of interests.

\section{Supplementary material}

Supplementary material associated with this article can be found, in the online version, at https://rcm.imrpress.com/EN/ 10.31083/j.rcm.2020.03.104.

Submitted: May 27, 2020

Revised: July 27, 2020

Accepted: August 03, 2020

Published: September 30, 2020

\section{References}

Badr, S., Minha, S., Kitabata, H., Fatemi, O., Torguson, R., Suddath, W. O., Satler, L. F., Pichard, A. D. and Waksman, R. (2015) Safety and long-term outcomes after percutaneous coronary intervention in patients with human immunodeficiency virus. Catheterization and Cardiovascular Interventions 85, 192-198.

Baumgartner, H., Falk, V., Bax, J. J., Bonis, M. D., Hamm, C., Holm, P. J., Iung, B., Lancellotti, P., Lansac, E., Munoz, D. R., Rosenhek, R., Sjögren, J., Mas, P. T., Vahanian, A., Walther, T., Wendler, O., Windecker, S. and Zamorano, J. L. (2017) 2017 ESC/EACTS Guidelines for the management of valvular heart disease. European Heart Journal 38, 2739-2791.

Bernelli, C., Danzi, G. B., Cerrato, E., Pierini, S., Ornaghi, M. G., Botta, L., Gentile, F., Migliorino, G. M. and Squillace, N. (2020) Cardiovascular events recurrence and coronary artery disease in HIV patients: the price we have to pay for the chronicization of the disease. Canadian Journal of Cardiology 36, 127-134.

Boccara, F., Cohen, A., Angelantonio, E., Meuleman, C., Ederhy, S., Dufaitre, G., Odi, G., Teiger, E., Barbarini, G. and Barbaro, G. (2008) Coronary artery bypass graft in HIV-infected patients: a multicenter case control study. Current HIV Research 6, 59-64.

Brogan, T. V., Thiagarajan, R. R., Department of Pediatrics, Harvard Medical School, Boston, MA, USA, Lorusso, R., McMullan, D. M., Di Nardo, M., Ogino, M. T., Dalton, H. J., Burke, C. R. and Capatos, G. (2020) The use of extracorporeal membrane oxygenation in human immunodeficiency virus-positive patients: a review of a multicenter database. Perfusion 2017, 026765912090696.

Brozzi, N. A., Simkins, J., Cifuentes, R. O., Ghodsizad, A., Thakkar Rivera, N. and Loebe, M. (2020) Advanced heart failure therapies in patients with stable HIV infection. Journal of Cardiac Surgery 35, 908911.

Bundhun, P. K., Pursun, M. and Huang, W. (2017) Does infection with human immunodeficiency virus have any impact on the cardiovascular outcomes following percutaneous coronary intervention?: a systematic review and meta-analysis. BMC Cardiovascular Disorders 17, 190.

Chong, T., Alejo, D. E., Greene, P. S., Redmond, J. M., Sussman, M. S., Baumgartner, W. A. and Cameron, D. E. (2003) Cardiac valve replacement in human immunodeficiency virus-infected patients. The Annals of Thoracic Surgery 76, 478-481.

Clement, M. E., Lin, L., Navar, A. M., Okeke, N. L., Naggie, S. and Douglas, P. S. (2018) Lower likelihood of cardiac procedures after acute coronary syndrome in patients with human immunodeficiency virusacquired immunodeficiency syndrome. Medicine 97, e9849.

Corral-Velez, V., Lopez-Delgado, J., Betancur-Zambrano, N., LopezSune, N., Rojas-Lora, M., Torrado, H. and Ballus, J. (2015) The inflammatory response in cardiac surgery: an overview of the pathophysiology and clinical implications. Inflammation \& Allergy-Drug Targets 13, 367-370.

D'Ascenzo, F., Cerrato, E., Biondi-Zoccai, G., Moretti, C., Omede, P., Sci- uto, F., Bollati, M., Modena, M. G., Gaita, F. and Sheiban, I. (2012) Acute coronary syndromes in human immunodeficiency virus patients: a meta-analysis investigating adverse event rates and the role of antiretroviral therapy. European Heart Journal 33, 875-880.

Deeks, S. G., Overbaugh, J., Phillips, A. and Buchbinder, S. (2015) HIV infection. Nature Reviews Disease Primers 1, 15035.

Erqou, S., Jiang, L., Choudhary, G., Lally, M., Bloomfield, G. S., Zullo, A. R., Shireman, T. I., Freiberg, M., Justice, A. C., Rudolph, J., Lin, N. and Wu, W. (2020) Heart Failure Outcomes and Associated Factors Among Veterans With Human Immunodeficiency Virus Infection. JACC: Heart Failure 8, 501-511.

Erqou, S., Lodebo, B. T., Masri, A., Altibi, A. M., Echouffo-Tcheugui, J. B., Dzudie, A., Ataklte, F., Choudhary, G., Bloomfield, G. S., Wu, W. and Kengne, A. P. (2019) Cardiac dysfunction among people living with HIV. JACC: Heart Failure 7, 98-108.

Feinstein, M. J., Bahiru, E., Achenbach, C., Longenecker, C. T., Hsue, P., So-Armah, K., Freiberg, M. S. and Lloyd-Jones, D. M. (2016) Patterns of cardiovascular mortality for HIV-infected adults in the United States: 1999 to 2013. The American Journal of Cardiology 117, 214-220.

Freiberg, M. S., Chang, C. H., Kuller, L. H., Skanderson, M., Lowy, E., Kraemer, K. L., Butt, A. A., Bidwell Goetz, M., Leaf, D., Oursler, K. A., Rimland, D., Rodriguez Barradas, M., Brown, S., Gibert, C., McGinnis, K., Crothers, K., Sico, J., Crane, H., Warner, A., Gottlieb, S., Gottdiener, J., Tracy, R. P., Budoff, M., Watson, C., Armah, K. A., Doebler, D., Bryant, K. and Justice, A. C. (2013) HIV infection and the risk of acute myocardial infarction. JAMA Internal Medicine 173, 614

Giacinto, O., Satriano, U., Nenna, A., Spadaccio, C., Lusini, M., Mastroianni, C., Nappi, F. and Chello, M. (2019) Inflammatory response and endothelial dysfunction following cardiopulmonary bypass: pathophysiology and pharmacological targets. Recent Patents on Inflammation \& Allergy Drug Discovery 13, 158-173.

Hauguel-Moreau, M., Boccara, F., Boyd, A., Salem, J., Brugier, D., Curjol, A., Hulot, J., Kerneis, M., Galier, S., Cohen, A., Montalescot, G., Collet, J. and Silvain, J. (2017) Platelet reactivity inhuman immunodeficiency virusinfected patients on dual antiplatelet therapy for an acute coronary syndrome: the EVERE2ST-HIV study. European Heart Journal 38, 1676-0686.

Koval, C. E., Farr, M., Krisl, J., Haidar, G., Pereira, M. R., Shrestha, N., Malinis, M. F., Mueller, N. J., Hannan, M. M., Grossi, P. and Huprikar, S. (2019) Heart or lung transplant outcomes in HIV-infected recipients. The Journal of Heart and Lung Transplantation 38, 1296-1305.

Longenecker, C. T., Webel, A. R. and Lloyd-Jones, D. M. (2020) Prevention as treatment: A bold vision for improving the cardiovascular health of people living with HIV. Progress in Cardiovascular Diseases 63, 77-78.

Manga, P., McCutcheon, K., Tsabedze, N., Vachiat, A. and Zachariah, D. (2017) HIV and nonischemic heart disease. Journal of the American College of Cardiology 69, 83-91.

Manmathan, G., Little, C., Barber, T. J., Burns, F. and Rakhit, R. D. (2020) Death, heart failure, and HIV. JACC: Heart Failure 8, 248-249.

Mestres, C. (2003) Long-term results after cardiac surgery in patients infected with the human immunodeficiency virus type-1 (HIV-1). European Journal of Cardio-Thoracic Surgery 23, 1007-1016.

Moran, C. A., Southmayd, G., Devireddy, C. M., Quyyumi, A. A., Ofotokun, I., Liberman, H. A., Jaber, W. and Sheth, A. N. (2020) Clinical and procedural characteristics of persons living with HIV presenting with acute coronary syndrome. Aids 34, 81-90.

Nishimura, R. A., Otto, C. M., Bonow, R. O., Carabello, B. A., Erwin, J. P., Fleisher, L. A., Jneid, H., Mack, M. J., McLeod, C. J., O'Gara, P. T., Rigolin, V. H., Sundt, T. M. and Thompson, A. (2017) 2017 AHAACC focused update of the 2014 AHAACC guideline for the management of patients with valvular heart disease. Journal of the American College of Cardiology 70, 252-289.

Nou, E., Lo, J., Hadigan, C. and Grinspoon, S. K. (2016) Pathophysiology and management of cardiovascular disease in patients with HIV. The Lancet Diabetes \& Endocrinology 4, 598-610.

Pallikkuth, S., Pahwa, R., Kausalya, B., Saravanan, S., Pan, L., Vignesh, R., Iqbal, S., Solomon, S. S., Murugavel, K. G., Poongulali, S., Kumarasamy, N. and Pahwa, S. (2018) Cardiac morbidity in HIV infec- 
tion is associated with checkpoint inhibitor LAG-3 on CD4 T cells. Plos One 13, e0206256.

Peck, R. N. and Kingery, J. R. (2020) Immunology of hypertension in people with HIV. Journal of the American Heart Association 9, e015725.

Polanco, A., Itagaki, S., Chiang, Y. and Chikwe, J. (2014) Changing prevalence, profile, and outcomes of patients with HIV undergoing cardiac surgery in the United States. American Heart Journal 167, 363-368.

Rethy, L., Feinstein, M. J., Sinha, A., Achenbach, C. and Shah, S. J. (2020) Coronary microvascular dysfunction in HIV: a review. Journal of the American Heart Association 9, e014018.

Robich, M. P., Schiltz, N., Johnston, D. R., Mick, S., Tse, W., Koch, C. and Soltesz, E. G. (2014) Outcomes of patients with human immunodeficiency virus infection undergoing cardiovascular surgery in the United States. The Journal of Thoracic and Cardiovascular Surgery 148, 3066-3075.

Siegfried, N., Uthman, O. A. and Rutherford, G. W. (2010) Optimal time for initiation of antiretroviral therapy in asymptomatic, HIVinfected, treatment-naive adults. Cochrane Database of Systematic Reviews 2010, CD008272.

Sinha, A. and Feinstein, M. (2020) Epidemiology, pathophysiology, and prevention of heart failure in people with HIV. Progress in Cardiovascular Diseases 63, 134-141.

Sinha, A. and Feinstein, M. J. (2019) Coronary artery disease manifestations in HIV: what, how, and why. Canadian Journal of Cardiology 35, 270-279.

Squiccimarro, E., Labriola, C., Malvindi, P. G., Margari, V., Guida, P., Visicchio, G., Kounakis, G., Favale, A., Dambruoso, P., Mastrototaro, G., Lorusso, R. and Paparella, D. (2019) Prevalence and clinical impact of systemic inflammatory reaction after cardiac surgery. Journal of Cardiothoracic and Vascular Anesthesia 33, 1682-1690.

Stein, J. H., Currier, J. S. and Hsue, P. Y. (2014) Arterial disease in patients with human immunodeficiency virus infection. JACC: Cardiovascular
Imaging 7, 515-525.

Subramanian, S., Tawakol, A., Burdo, T. H., Abbara, S., Wei, J., Vijayakumar, J., Corsini, E., Abdelbaky, A., Zanni, M. V., Hoffmann, U., Williams, K. C., Lo, J. and Grinspoon, S. K. (2012) Arterial inflammation in patients with HIV. JAMA 308, 379

Sullivan, C. E., Serhal, M. and Longenecker, C. T. (2015) Cardiovascular surgery outcomes of patients with human immunodeficiency virus infection: New data in the era of combination antiretroviral therapy. The Journal of Thoracic and Cardiovascular Surgery 149, 1460.

Titanji, B., Gavegnano, C., Hsue, P., Schinazi, R. and Marconi, V. C. (2020) Targeting inflammation to reduce atherosclerotic cardiovascular risk in people with HIV infection. Journal of the American Heart Association 9, e014871.

Trachiotis, G. D., Alexander, E. P., Benator, D. and Gharagozloo, F. (2003) Cardiac surgery in patients infected with the human immunodeficiency virus. The Annals of Thoracic Surgery 76, 1114-1118.

Tseng, Z. H., Secemsky, E. A., Dowdy, D., Vittinghoff, E., Moyers, B., Wong, J. K., Havlir, D. V. and Hsue, P. Y. (2012) Sudden cardiac death in patients with human immunodeficiency virus infection. Journal of the American College of Cardiology 59, 1891-1896.

Vachiat, A., McCutcheon, K., Tsabedze, N., Zachariah, D. and Manga, P. (2017) HIV and ischemic heart disease. Journal of the American College of Cardiology 69, 73-82.

Wong, C. Y., Zhu, W., Aurigemma, G. P., Furukawa, N., Teshale, E. H., Huang, Y. A., Peters, P. J. and Hoover, K. W. (2020) Infective endocarditis among persons aged 18-64 years with HIV, hepatitis C infection, or opioid use disorder - United States, 2007-2017. Clinical Infectious Diseases : an Official Publication of the Infectious Diseases Society of America (in press).

Yanagawa, B., Verma, S., Dwivedi, G. and Ruel, M. (2019) Cardiac surgery in HIV patients: state of the Art. Canadian Journal of Cardiology 35, 320-325. 